\title{
BENTHIC COMMUNITY ANALYSIS AND THE PREDICTION OF ORGANIC CARBON CONTENT IN MESOZOIC BLACK SHALE FACIES
}

SAGEMAN*, Bradley B., Department of Geosciences, Penn State University, University Park, PA 16802; KAUFFMAN, Erle G., CB 250, Department of Geological Sciences, University of Colorado, Boulder, CO 80309

The burial and preservation of significant quantities of marine organic matter in epicontinental basins results from low bottom water oxygen levels, and moderate to low sedimentation rates of fine-grained siliciclastic sediment under at least moderately productive waters. Because benthic biotas are extremely sensitive to such factors as bottom water oxygen, grain size, substrate consistency and sedimentation rate, there is a potentially predictive relationship between biofacies and Corg potential of marine strata. High-resolution biological, sedimentological and geochemical studies of Mesozoic organic-rich black shale facies, comprising major hydrocarbon source rocks, allow characterization of this relationship: a) A series of recurrent, bivalve-dominated benthic communities are defined based on trends in diversity, abundance, equitability and trophic specialization. They comprise biofacies which reflect oxygen and substrate gradients in time and space, and thus the Corg preservation potential of marine sediments/strata. The biotas are surprisingly robust in terms of population size and inferred biomass, and demonstrably colonized the benthic zone (as opposed to pseudoplanktic origins). They include both resident communities of taxa specifically adapted to low oxygen (dysoxic) conditions through physiological and anatomical means (e.g., expanded oxygen adsorptive surfaces), or possibly through bacterial chemosymbiosis, and event communities of less tolerant taxa reflecting short-term improvements in benthic conditions; b) many organic-rich sequences contain common event biofacies, indicating a dynamic benthic environment with frequent short-term fluctuations in oxygen and substrate. These are attributable to mixing during large storms, productivity blooms, rapid deposition from mass flows, or reduced sedimentation during condensation/bypass events. However, increasing frequency of events is not necessarily correlated with decrease in Corg levels; c) comparison of trends in the quantity and quality of Corg to biofacies patterns indicate that the most favorable Corg preservation is associated with"benthic boundary biofacies." These biofacies represent a redox boundary at or near the sediment-water interface and a predominantly dysoxic to episodically oxic water column. The "benthic boundary" may have been associated with the presence of microbial (mainly sulphur bacterial) mats on the substrate surface, which could have regulated its position and contributed to the pool of sedimented Corg; d) mapping of benthic boundary biofacies in time and space within a basin makes possible correlation of Corg preservation potential to paleogeography and sea level history. Although the results of such analyses from the Greenhorn Formation, Western Interior basin, suggest highest Corg burial and preservation in fine-grained shale facies of distal offshore environments during sea level rise, high Corg is not necessarily associated with an anoxic water column. This suggests the need for reappraisal of stagnant basin scenarios for source rock formation. The most important factors in Corg accumulation and preservation may be the development of benthic boundaries and consequent maintenance of anoxia below the sediment-water interface in fine-grained, organic-rich substrates, and the contribution of bacteria to the flux of Corg into the sediment. 